\title{
USE OF INDICATOR MINERALS IN DIAMOND EXPLORATION: A COMPARISON BETWEEN BARREN AND FERTILE KIMBERLITES IN ANGOLA
}

\author{
Castillo-Oliver* $\mathrm{M}^{\mathbf{1}}$, Galí $\mathrm{S}^{\mathbf{1}}$, Gonçalves $\mathrm{AO}^{\mathbf{2}}$, Melgarejo $\mathrm{JC}^{\mathbf{1}}$ \\ 1. Dept. Cristal-lografia, Mineralogia i Dipòsits Minerals, Fac. de Geologia, Universitat de Barcelona. C/ Martí $i$ \\ Franquès, S/N,08028 Barcelona (*montgarricastillo@ub.edu) \\ 2. Dept. Geologia, Universidade Agostinho Neto, Luanda
}

\section{INTRODUCTION}

Mining companies have destined many resources on the characterization of kimberlitic deposits, in order to optimize the exploration stage and quickly discriminate between barren and fertile kimberlites. Compositions of some indicator minerals, such as Mg-ilmenite, chromite, garnet and diopside, are assumed to be strongly related to the diamond occurrence in kimberlites.

However, a recent publication by RoblesCruz et al. (2008) states the presence of a secondary Mg-ilmenite, replacing an early intercumulus Fe-rich ilmenite in the Catoca diamondiferous kimberlite (Angola). As a result, routine chemical analyses on mineral concentrates of ilmenite do not seem to be suitable for determining the diamond grades in this pipe, unless textural observations are considered.

Therefore, the aim of our research is to evaluate the effectiveness of the geochemical analyses of indicator minerals in diamond exploration, focusing on the textural populations observed in thin section.

\section{METHODS}

More than 50 samples from fertile and barren kimberlites were provided by ENDIAMA and De Beers companies from two separate areas in Angola. They were all studied both in thin and polished section, by using petrographic microscope in transmitted and reflected light. Different textural populations of the main indicator minerals have been characterized by SEM-EDS and their chemical composition has been determined by using a four dispersive WDS CAMECA SX50 EMP.

\section{GEOLOGICAL SETTING}

Angola, located in the Congo craton, is one of the main diamond producers in the world, because of its high concentration of economic kimberlites, especially at the northestern region of the country. However, very few publications are available from these kimberlites due to its particular historical context.

For this study, four kimberlites were sampled: two are from the Lunda province (NE Angola; samples H1-diamoniferous and H2barren), where there are large, well-known kimberlite clusters; and two from Andulo in the Bié province (centre Angola; A1-diamondiferous and A2- barren), where large carbonatite intrusions are known.

As it occurs in other nearby kimberlites, the emplacement of these four pipes is controlled by the Lucapa corridor, an extensional tectonic structure which crosses the country from NE (Lundas) to SW (Namibe), for more than 1100 $\mathrm{km}$ (Egorov et al., 2007). The age of the emplacement is assumed to be Lower Cretaceous, 


\section{0 $^{\text {th }}$ International Kimberlite Conference, Bangalore - 2012}

as it is strongly related to the other already dated kimberlitic eruptions of the area (Robles-Cruz et al, 2010).

\section{PETROGRAPHY OF THE KIMBERLITES}

Most of the samples come from the crater facies of the kimberlites, and are composed of a very finegrained, serpentinized matrix, quartz and olivine xenocrysts and different types of xenoliths. The latter are usually recovered by a thin rim of pelletal lapilli.

The proportion and diameter of the xenoliths in different samples is quite variable $(\mathrm{mm}-\mathrm{cm})$. There is a clear predominance of granitic rocks over the rest of xenoliths, although amphibolite xenoliths are also common. The Bié samples present abundant carbonatitic xenoliths, mainly composed of calcite. These xenoliths are probably related to the carbonatites emplaced close to the studied kimberlites. Scarce MARID and peridotite xenoliths may be also found.

The most abundant xenocrysts are those of forsterite, which are completely pseudomorfized to lizardite and calcite. Quartz and feldspar grains coming from disaggregation of granitic xenoliths are also abundant. Ilmenite, diopside and garnet are the most common indicator minerals found as megacrysts, and are interpreted as xenocrysts. Minor amounts of phlogopite, rutile, zircon and monazite-(Ce) were also found.

Finally, the matrix is mainly composed of antigorite, which replaces the original mafic silicate matrix, and magnetite partly altered to hematite; calcite is common as pseudomorphs and in veinlets. The matrix has indicator minerals, submillimetric in size, as chromite and perovskite.

\section{TEXTURES AND GEOCHEMISTRY OF THE INDICATOR MINERALS}

\section{CHROMITE}

Four types of chromite were found: Chromite as olivine inclusions: small euhedral crystals $(<30 \mu \mathrm{m})$ were observed inside completely serpentinized xenocrysts of olivine, in fertile and barren kimberlites.

- Atoll chromite appears in the matrix of all studied kimberlites. They have a core composed of euhedral chromite mantled by a $5 \mu \mathrm{m}$ thick ulvöspinel rim. An intermediate ring is commonly occupied by serpentine and/ or calcite (fig. 1).

- Fine grained chromite in xenoliths: anhedral small crystals appear both in eclogitic and MARID xenoliths.
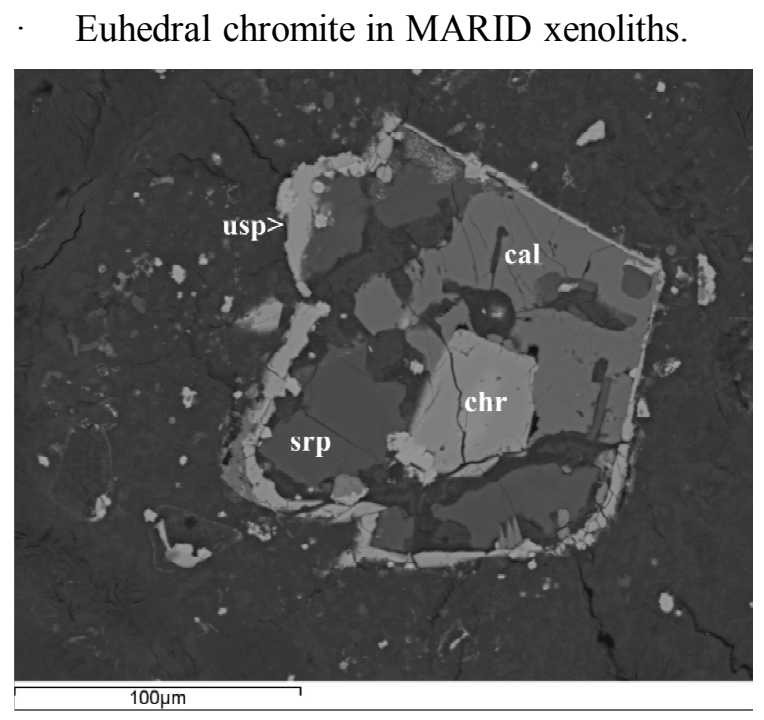

Fig. 1: Atoll spinel in the serpentinized matrix from the diamondiferous kimberlite of Lucapa. Core is composed of chromite (chr), the intermediate ring is made up by calcite (cal) and serpentine (usp), and the outer rim is composed of ulvöspinel (usp).

Generally chromite from fertile pipes has low $\mathrm{TiO}_{2}$ and high $\mathrm{Cr}_{2} \mathrm{O}_{3}$ content. In addition, the composition of the chromite of the groundmass is always far from that found in spinel grains included in diamond (Fipke, 1991), whereas the chromite in xenoliths usually presents compositions close to it.

Zoning is present in chromite grains, and two trends were defined from the core to the rims:

a. $\mathrm{TiO}_{2}$ and $\mathrm{Fe}^{3+}$ enrichment with simultaneous $\mathrm{Cr}_{2} \mathrm{O}_{3}$ decrease in the atoll chromite. This trend 


\section{0 $^{\text {th }}$ International Kimberlite Conference, Bangalore - 2012}

has also been observed in Catoca and it is similar to that of Roeder et al, 2008.

b. $\mathrm{Fe}^{3+}$ enrichment with $\mathrm{Cr}_{2} \mathrm{O}_{3}$ decrease at constant $\mathrm{TiO} 2$, typical of the chromite in olivine.

\section{Ilmenite}

Four different textural populations of ilmenite were characterized:

- Anhedral ilmenite xenocrysts: although their size can range from 50 to $600 \mu \mathrm{m}$, they are all homogeneous in composition. Some grains are overgrown by $\mathrm{Nb}$-rutile.

- Ilmenite with ulvöspinel exsolutions (fig.2).

- Ilmenite exsolutions in ulvöspinel.

- Polycrystalline ilmenite cumulates: in some cases they can be slightly replaced by rutile or hematite along grain boundaries.

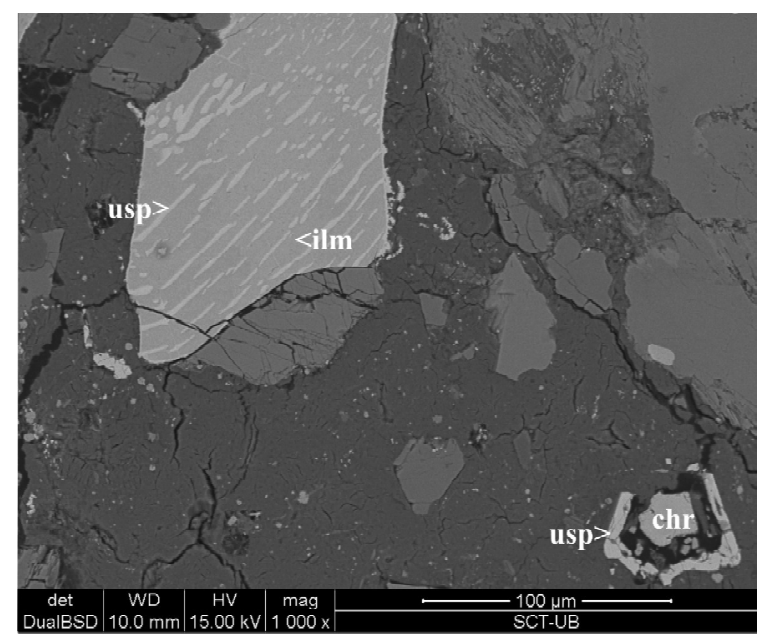

Fig. 2: Ilmenite xenocrysts (ilm), with fine ulvöspinel exsolutions, set in a serpentinized matrix. An "atoll" spinel crystal, with chromite (chr) in the core and ulvöspinel (usp) rim, can also be observed.

Anhedral ilmenite xenocrysts and cumulates have a high $\mathrm{Mg}$ content, thus they fit in the "kimberlitic" ilmenite field in the $\mathrm{MgO}-\mathrm{TiO}_{2}$ diagram (Wyatt, 2004). However, ilmenite with ulvöspinel exsolutions systematically falls out of this field. When represented in the $\mathrm{Fe}_{2} \mathrm{O}_{3}-\mathrm{MgO}$ diagram (Gurney \& Zweistra, 1995) and the MgO$\mathrm{Cr}_{2} \mathrm{O}_{3}$ diagram (Smith et al, 1991) (fig.3), they do

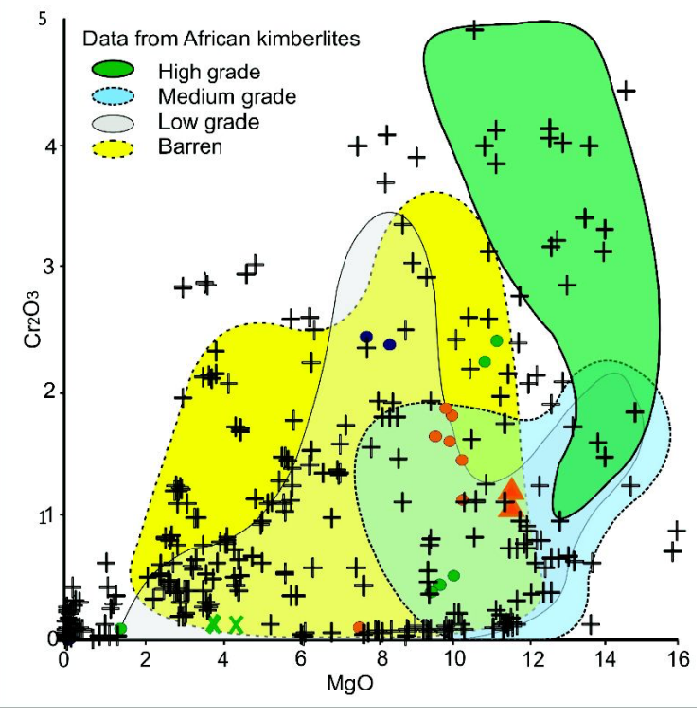

Fig. 3: $\mathrm{MgO}-\mathrm{Cr}_{2} \mathrm{O}_{3}$ Diagram modified from Smith et al. (1991), elaborated with ilmenite data of African kimberlites. It does not allow distinguishing between the fertile (green and dark blue circles) and barren kimberlites (orange circles and triangles). In addition, less than $5 \%$ of the ilmenite grains from Catoca (crosses) fall in the field of high grade kimberlites, although it is one of the main diamond mines in the world.

not reflect at all the preservation grade of the diamonds, since the grains coming from diamondiferous kimberlites usually plot in low grade preservation. Similar results were published by Robles-Cruz et al. (2008).

\section{Garnet}

Garnet can appear both as a xenocryst and inside a xenolith, usually as porphyroblast in amphibolites or schists. Locally they also occur in eclogite and garnet peridotite xenoliths and, therefore, can give more information on the composition and characteristics of the lower mantle.

Unlikely to those from the Catoca pipe, garnet xenocrysts from Lucapa and Bié kimberlites are usually very poor in $\mathrm{Cr}_{2} \mathrm{O}_{3}(<1$ $\mathrm{wt} \%)$ and have a wide range of $\mathrm{CaO}$ content (1.23$14 \mathrm{wt} \%)$. However, lack of lherzolitic and harzburgitic garnet xenocrysts in these pipes could be explained by scarce sampling. 


\section{0 $^{\text {th }}$ International Kimberlite Conference, Bangalore - 2012}

\section{Cr-rich diopside}

Due to the high alteration degree of these pipes, few diopside grains were preserved. However, three different textural populations could be distinguished:

- Clinopyroxene in xenoliths: it has a prismatic habit and is commonly found with garnet in deep xenoliths.

- Groundmass diopside: it has a grain size ranging from 20 to $100 \mu \mathrm{m}$ and is commonly altered along grain boundaries.

- Groundmass skeletal diopside

Two geochemical types of clinopyroxene were distinguished: those with $\mathrm{Cr}_{2} \mathrm{O}_{3}>1 \mathrm{wt} \%$, interpreted as xenocrysts of a garnet peridotite; and those with lower values, of eclogitic origin.

\section{PEROVSKITE}

Only some small $(<40 \mu \mathrm{m})$ perovskite grains were found in our samples. They form euhedral pseudocubic crystals, replaced by anatase.

All the analysed grains are kimberlitic perovskite sensu strictu, with low REE, $\mathrm{Sr}, \mathrm{Nb}$ and $\mathrm{Na}$ contents.

\section{DISCUSSION}

Next conditions are essential for a kimberlite to be diamondiferous:

1. The sampled mantle is fertile (inside the diamond stability field and with an available C source);

2. The diamond can be preserved, by the absence of oxidising processes at high temperature during the emplacement of the kimberlite; and a fast ascent rates towards the surface.

The fertility of the mantle beneath the Lucapa kimberlites is supported by thermobarometric calculations; since most of the data obtained by using single-Cpx thermobarometer (Nimis \& Taylor, 2000) plot in the diamond stability field. The results (fig.4) also

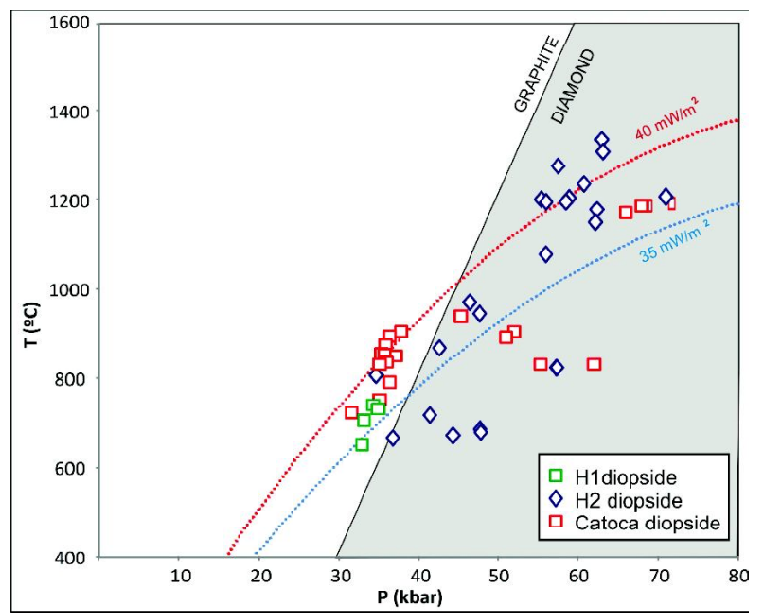

Fig. 4. Crystallization conditions of the garnet peridotite pyroxenes from the diamondiferous (H1) and barren (H2) kimberlites of Lucapa and some data from Catoca.

show a low heat flow $\left(40 \mathrm{~mW} / \mathrm{m}^{2}\right)$, which is positive for the diamond preservation (Gurney et al., 1979).

A second argument in favour of the presence of diamonds in the mantle beneath Angola is the composition of some chromite grains from xenoliths, which show compositions close to those found as inclusions in diamond. Nevertheless, the presence of a $\mathrm{Fe}^{3+}$-rich ilmenite should not be considered as a solid argument to reject the exploitation of a kimberlite, since it has been found in diamondiferous pipes.

However, zoning and textural features of the groundmass chromite show that all the kimberlites studied were affected to a greater or lesser degree by oxidising processes. The $\mathrm{Fe}^{3+}$ enrichment trend observed in this spinel and the presence of antigorite (high temperature serpentine), replacing the original groundmass, would indicate an environment which could facilitate the destruction of the diamonds, especially those that were initially in the groundmass.

Finally, the wide range of compositions observed in chromite, pyroxene and ilmenite grains in a single kimberlite suggests that a heterogeneous mantle has been sampled. This 
heterogeneity might explain the duality between barren and diamondiferous kimberlites in the Lundas and Bié provinces, related to the presence or absence of a carbon source at depth.

\section{CONCLUSION}

Although commonly the geochemical composition of the indicator minerals is used with independence of their textural features, in this study this criterion is only valid for Cr-diopside. Contrastingly, the other analysed indicator minerals show compositional variations according to the different observed textural types. As a result, if textural populations are not taken into account, a misinterpretation of the geochemical data could easily occur and this would prevent the correct evaluation of the diamond potential of the pipes. Finally, mineral textures have also given significant information about the kimberlite emplacement processes and the diamond grade of these pipes.

\section{Acknowledgements}

This research was supported by the project CGL2009-13758 (BTE) and the AGAUR SGR 444. The authors also acknowledge ENDIAMA for providing the samples, as well as the technicians of the CCiT-UB for assistance in the use of SEM/ESEM-BSE-EDS analyses and EMP.

\section{References}

Egorov, K.N., Roman'ko, E.F., Podvysotsky, V.T., Sablukov, S.M., Garanin, V.K., D'yakonov, D.B. (2007): New data on kimberlite magmatism in southwestern Angola. Rus. Geo!. Geophys. 48, 323-336.
Fipke, C. (1991): Significance of chromite, ilmenite, G5 Mg-almandine garnet, zircon and tourmaline in heavy mineral detection of diamond bearing lamproite. In Diamonds: Characterization, Genesis and Exploration (H.O.A. Meyer \& O.H. Leonardos, eds.). Proc. 5th Int. Kimb. Conf. 2, CPRM Spec. Publ. 2, Brazil (366-381)

Gurney, J., Zweistra, P. (1995): The interpretation of the major element composition of mantle minerals in diamond exploration. J. Geochem. Explor. 53, 293--309.

-, Harris, J., Rickard, R. (1979): Silicate and oxide inclusions from the Finsch kimberlite pipe. In Kimberlites, diatremes and diamonds: their geology, petrology and geochemistry (F. Boyd \& 0 . Meyer, eds.) Proc. 2nd Int. Kimberlite Confl, (1-15).

Nimis, P., Taylor, W. (2000): Single clinopyroxene thermobarometry for garnet peridotites. Part I: Calibration and testing of a Cr-in-Cpx barometer and an enstatite-in-Cpx thermometer. Contrib. Mineral. Petrol. 139, 541-554.

Robles-Cruz, S., Watangua, M., Isidoro, L, Melgarejo, J. (2008): Contrasting compositions and textures of ilmenite in the Catoca kimberlite, Angola, and implications in exploration for diamond. Lithos 112s, 966-975.

-, Escayola M, Davis B, Galí S, Watangua M, Pervov VA, Melgarejo JC (2010) SHRIMP U-Pb zircon ages from Catoca and Tchiuzo kimberlites, Angola: VII South Amer. Symp. on Isotope Geol. (SSAGI), Brasil

Roeder, P., Schulze, D. (2008): Crystallization of groundmass spinel in kimberlite. J. Petrol. 49(8), 1473-1495.

Smith, C., Lucas, H., Hall, A., Ramsay, J. (1991): Diamond prospectivity and indicator mineral chemistry: a Western Australian perspective. Proc. 5th Int. Kimberlite Conf. 2, CPRM Spec. Publ. 2, Brasilia, Brazil, (312-318).

Wyatt, B., Baumgartner, M., Anckar, E., Grutter, H. (2004): Composicional classification of "kimberlitic" and "non-kimberlitic" ilmenite. Lithos 77: 819-840. 